\title{
Assessment of Genetic Relationship among Male and Female Fig Genotypes Using Simple Sequence Repeat (SSR) Markers
}

\author{
Sevin TEOMAN ${ }^{1}$, Meryem IPEK ${ }^{1}$, Umran ERTURK ${ }^{1}$, Nesrin AKTEPE \\ TANGU $^{2}$, Erdem DURGUT ${ }^{3}$, Erdogan BARUT ${ }^{1}$, \\ Sezai ERCISLI ${ }^{4}$, Ahmet IPEK $^{1 *}$
}

\author{
${ }^{1}$ University of Uludağ, Faculty of Agriculture,Department of Horticulture,Bursa,Turkey; sevinteoman@uludag.edu.tr; msipek@uludag.edu.tr; \\ umrane@uludag.edu.tr; ebarut@uludag.edu.tr;maipek@uludag.edu.tr (*correspondingauthor) \\ ${ }^{2}$ Atatürk Horticultural Central Research Institute, Bursa, Turkey; nesrintangu1@hotmail.com \\ ${ }^{3}$ Bursa Directorate of Provincial Food Agriculture and Livestock, Bursa, Turkey; edurgut22@mynet.com \\ ${ }^{4}$ University of Ataturk, Faculty of Agriculture, Department of Horticulture, Erzurum, Turkey; sercisli@gmail.com
}

\begin{abstract}
Fig (Ficus carica L.) is a traditional crop in Turkey and widely cultivated around the Mediterranean areas. The gynodioecious fig species is present in two sexual forms, i.e. the domesticated fig (female tree) and the caprifig (male tree). Caprifigs are crucial for high quality fig production and breeding while, the studies on assessment of genetic relationship among caprifigs is limited. The aim of this study was to determine genetic diversity among 45 caprifigs and 2 female figs collected from four provinces in Marmara and Aegean Sea Regions of Turkey using simple sequence repeat (SSR) markers. In this work, 24 SSR markers were tested, one was monomorphic and the remaining markers amplified 82 alleles. The number of polymorphic alleles per SSR marker ranged from 2 to 7 . The observed heterozygosity (Ho) differed from 0.18 to 0.76 and expected heterozygosity $(\mathrm{He})$ ranged between 0.24 and 0.81 . The polymorphism information content (PIC) varied from 0.42 to 0.98. A UPGMA analysis based on Dice similarity matrix clustered fig genotypes into two main groups and similarly, STRUCTURE analysis placed fig genotypes into two different gene pools $(K=2)$. Fig genotypes collected from the same region were not clustered together in a group indicating that the fig genotypes did not cluster on the basis of their collection sites. Our results demonstrated that caprifigs and female figs are not genetically distinct and they clustered together in a group. All fig genotypes had distinct SSR marker profiles suggesting that there were no synonyms or homonyms. These results revealed a high genetic variation among fig genotypes and 23 SSR markers were enough to discriminate all fig genotypes analysed in this study demonstrating that SSR marker system is suitable for genetic analysis in figs.
\end{abstract}

Keywords: caprifig, Ficus carica L., genetic variation, SSR marker, STRUCTURE analysis

\section{Introduction}

Fig (Ficus carica L.) has been cultivated since ancient times in the world (Janick, 2005) and Mediterranean region where Turkey is located is the origin of common figs (Caliskan and Polat, 2008). Traditionally, figs are an important ingredient in human diets in the region (Aksoy, 1998). Currently, they can be consumed as dried or fresh and excellent sources of vitamins, minerals, fiber and antioxidant compounds with health benefits (Caliskan et al., 2012; Mawa et al., 2013).

Due to its geographical and ecological conditions, Turkey is the major fig-producing country in the world. The world fig production in 2014 was 1.137 .730 tons and Turkey was the leading country with the production of $300.282 \mathrm{t}$ (26.3\%)
(FAOSTAT, 2014). According to Turkish Statistical Institute in 2015, the fig production in Turkey was mainly spread in the Aegean (76.3\%), Marmara (9.6\%) and Mediterranean (7.8\%) regions. In addition, Turkey has a remarkable dried fig export potential with $69.3 \%$ of worldwide dried fig export (FAOSTAT, 2013).

Figs are morphologically gynodioecious but functionally dioecious species having a specific reproduction system (Stover et al., 2007; Flaishman et al., 2008). Based on pollination mechanism, there are two sexual forms of fig, i.e. the caprifig (male tree), contain both male flowers and short-styled female flowers (abortive) together so that they can be described as morphologically hermaphrodite. Therefore, caprifigs can be used only as a pollen source for pollination and they don't 
produce any edible fruits. Male fig plants give three types of fruit annually; profichi (in summer), mammoni (in autumn) and mamme (in winter). Profichi (the main crop) is used for pollination of main summer crop of female trees (Ferguson $e t$ al., 1990). However, female fig plants, called edible figs, have long-styled female flowers and they can produce commercial fruits. Pollination process, also called caprification in ficus species, occurs by transferring pollen from caprifigs to female flowers of edible figs by a pollinator wasp, Blastophaga psenes $\mathrm{L}$. The wasp enters, oviposits and develops in caprifigs, so there has been a symbiotic relationship between Blastophaga psenes $\mathrm{L}$. and caprifigs (Kjelberg et al., 1987).

Although some parthenocarpic female fig genotypes require no pollination, caprification has become a common practice in commercial fig production in order to obtain sufficient fruit yield and high quality fruit set. Various studies reported that caprified fig fruits were larger and had more phytochemicals than uncaprified figs; and also caprification increased fruit weight and yield (Rahemi and Jafari, 2008; Trad et al., 2013). Pollination is required for many important Turkish female fig cultivars such as 'Bursa Siyahı' and 'Sarılop' which are well-known in Marmara and Aegean Regions, respectively. 'Bursa Siyahı' is one of the best cultivars for fruit quality and fresh consumption and 'Sarlop' is the well-known cultivar for dried fig production.

Due to the easy propagation of fig via cuttings, fig genotypes or cultivars can be transferred from one region to another region without any data. Therefore, it is crucial to characterize the local fig germplasm and discover genetic diversity among the fig accessions for intensive fig cultivation (Flaishman et al., 2008).

There have been various studies on the characterization of fig genotypes using of morphological traits (Caliskan and Polat, 2008; Giraldo et al., 2010; Pérez-Sánchez et al., 2016). However, morphological characters can be influenced by environmental factors. To overcome this limitation, molecular marker based analysis have been carried out using isoenzyme markers (Cabrita et al., 2001); RAPDs (Khadari et al., 1995; Dalkilic et al., 2011); AFLPs (Baraket et al., 2009); ISSR (Guasmi et al., 2006; Ikegami et al., 2009). Microsattelites or SSRs have become the choice of marker due to their high polymorphism, co-dominance and reproducibility in recent genetic diversity studies for fig cultivars (Khadari et al., 2001; 2004; Giraldo et al., 2005; 2008; Achtak et al., 2009; Çalışkan et al., 2012; Perez-Jiménez et al., 2012; Ganopoulos et al., 2015; Ferrara et al., 2016)

However, genetic characterization of caprifig germplasms using molecular markers such as SSR and RAPD is limited to few studies (Dalkilic et al., 2011; Essid et al., 2015). Thus, the purpose of this study was to investigate genetic relationship between 45 caprifig genotypes and 2 common Turkish female fig cultivars with SSR markers. The best caprifig genotypes as pollinators of important Turkish fig cultivars such as 'Sarılop' and 'Bursa Siyahi' are needed and in this respect, caprifig collection in Uludag University can serve as germplasm resources. Therefore, this study is important to assess and characterize the genetic relationship among caprifigs in this collection.

\section{Materials and Methods}

\section{Plantmaterial}

In this study, the genetic relationship between 47 fig genotypes was analyzed (Table 1). 'Bursa Siyahı' and 'Sarlop' are the common female fig cultivars while the remaining 45 genotypes were the caprifigs collected from Bursa, Yalova, Balkesir and Aydin provinces of Turkey (Fig. 1). Caprifig genotypes were collected to determine best pollinator genotypes for fig cultivars such as Bursa Siyahı' and 'Sarilop'.

Table 1. List of genotypes and their sites of collection

\begin{tabular}{|c|c|c|c|}
\hline Genotypes & Locations & Genotypes & Locations \\
\hline $16-05-01$ & Işıklı, Mudanya, Bursa & $16-Z F-02$ & Görükle, Bursa \\
\hline $16-05-03$ & Işıklı, Mudanya, Bursa & $16-Z F-03$ & Görükle, Bursa \\
\hline $16-05-04$ & Işıklı, Mudanya, Bursa & $16-Z F-04$ & Görükle, Bursa \\
\hline $16-05-08$ & Işıklı, Mudanya, Bursa & $16-Z F-05$ & Görükle, Bursa \\
\hline $16-05-10$ & Işıklı, Mudanya, Bursa & $16-Z F-06$ & Görükle, Bursa \\
\hline $16-05-12$ & Işıklı, Mudanya, Bursa & $16-Z F-07$ & Görükle, Bursa \\
\hline 16-09-09 & Nilüfer, Bursa & $16-Z F-08$ & Görükle, Bursa \\
\hline $16-09-10$ & Nilüfer, Bursa & 16-ZF-09 & Görükle, Bursa \\
\hline $16-09-11$ & Nilüfer, Bursa & $77-00-01$ & Yalova \\
\hline $16-08-05$ & Osmangazi, Bursa & 77-00-01-B & Yalova \\
\hline $16-08-06$ & Osmangazi, Bursa & $77-00-02$ & Yalova \\
\hline $16-08-07$ & Osmangazi, Bursa & Bursa Siyahı & Yalova \\
\hline 16-08-09 & Osmangazi, Bursa & Sarılop & Yalova \\
\hline $16-08-10$ & Osmangazi, Bursa & Havran & Balıkesir \\
\hline $16-08-12$ & Osmangazi, Bursa & Kaba İlek & Ömerbeyli, Aydın \\
\hline $16-00-01$ & Hürriyet, Bursa & Elma İlek & İmamköy, Aydın \\
\hline Bursa 1 & Osmangazi, Bursa & Mor Demirtaş & Kuyucak, Aydın \\
\hline $16-03-06$ & Karabalçık, Osmangazi, Bursa & Taşlık & Bozdoğan, Aydın \\
\hline $16-03-07$ & Karabalçık, Osmangazi, Bursa & Çakın 1 & Kuyucak, Aydın \\
\hline $16-03-08$ & Karabalçı, Osmangazi, Bursa & Kıbrislı & İmamköy, Aydın \\
\hline $16-07-01$ & Gürsu, Bursa & Yanako & Gümüşköy, Aydın \\
\hline $16-07-05$ & Gürsu, Bursa & Ak İlek & İmamköy, Aydın \\
\hline $16-07-06$ & Gürsu, Bursa & Karabulut & İmamköy, Aydın \\
\hline 16-ZF-01 & Görükle, Bursa & & \\
\hline
\end{tabular}




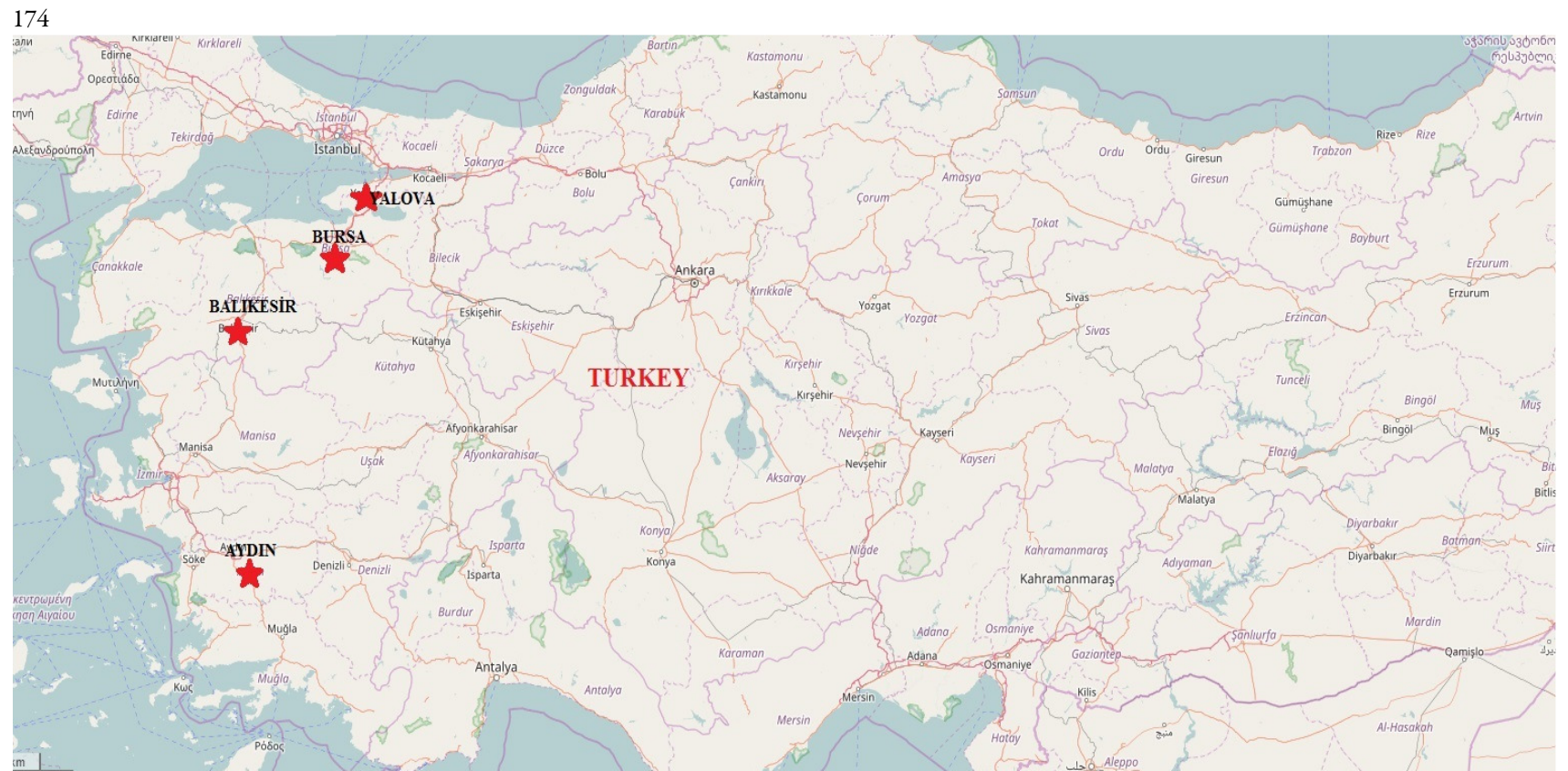

Fig. 1. The signs on the map indicates the provinces where leaf samples were collected (Source: http://www.openstreetmap.org/)

\section{DNA Extraction}

DNA extraction from young leaf samples were collected and powdered with a paint shaker after lyophilization. DNA samples were extracted from $25 \mathrm{mg}$ powdered leaf samples by using a modified CTAB method (Futterer et al., 1995). The concentration of each DNA sample was measured using a Quibit fluorometer (Invitrogen, USA) and adjusted to $50 \mathrm{ng} /$ $\mu \mathrm{L}$ and stored at $-80^{\circ} \mathrm{C}$ until use.

\section{SSR analysis}

Twenty four SSR primer pairs previously developed by Giraldo et al. (2005) were used for SSR analysis (Table 2). Forward primers were tailed with M13 sequence (GACGTTGTAAAACGACGGCC) at the $5^{\prime}$ end (Schuelke, 2000). Each $20 \mu \mathrm{L}$ PCR solution contained $1.0 \mathrm{U}$ Taq DNA polymerase (Thermo Scientific, USA) with $1 \times$ reaction buffer, $0.10 \mu \mathrm{M}$ M13 sequence tailed forward primer, $0.20 \mu \mathrm{M}$ reverse primer, $0.20 \mu \mathrm{M}$ M13 primer labelled with infrared dye either $700 \mathrm{~nm}$ or $800 \mathrm{~nm}$ (Licor, USA), $0.2 \mathrm{mM}$ dNTPs, and 50 ng of DNA. SSR makers were amplified with a Veriti 96 well thermal cycler (Applied Biosystems, USA) using the following thermal cycling condition: 2 min at $94^{\circ} \mathrm{C} ; 6$ cycles of $40 \mathrm{~s}$ at $94^{\circ} \mathrm{C}, 1 \mathrm{~min}$ at $60^{\circ} \mathrm{C}$ (annealing temperature was reduced $1{ }^{\circ} \mathrm{C}$ after every cycle for touchdown PCR protocol), 1 min and 30 s at $72{ }^{\circ} \mathrm{C} ; 28$ cycles of 40 s at $94^{\circ} \mathrm{C}, 1 \mathrm{~min}$ at $55^{\circ} \mathrm{C}$ and $1 \mathrm{~min}$ and $30 \mathrm{~s}$ at $72^{\circ} \mathrm{C} ; 7$ cycles of $40 \mathrm{~s}$ at $94^{\circ} \mathrm{C}, 1 \mathrm{~min}$ at 54 ${ }^{\circ} \mathrm{C}$ and $1 \mathrm{~min}$ and $30 \mathrm{~s}$ at $72^{\circ} \mathrm{C}$ and final extension step of 10 min at $72{ }^{\circ} \mathrm{C}$. The PCR products were separated on $7.5 \%$ polyacrylamide gels at $30 \mathrm{~W}$ for 2 to $3 \mathrm{~h}$ using a Li-COR 4300 automated sequencer system (LI-COR).

\section{Data analysis}

SSR markers were scored manually as present (1) or absent (0) and a genetic similarity matrix of fig genotypes was calculated using Dice coefficient (Dice, 1945) with the NTSYSpc v2.21 program (Exeter Software, New York, NY, USA). An unweight pair group method with arithmetic averages (UPGMA) dendrogram based on the Dice similarity matrix was constructed.
Expected heterozygosity $(\mathrm{He})$ and observed heterozygosity $(\mathrm{Ho})$ were calculated according to the method of Levene (1949) using POPGEN32 software v.1.32 (Yeh et al., 1997). The polymorphism information content (PIC) was calculated using the formula:

$$
P I C=1-\sum_{i=1}^{j} P_{i}^{2}-2 \sum_{i=j+1}^{j} \sum_{j=1}^{i-1} P_{i}^{2} P_{j}^{2}
$$

where $\mathrm{Pi}$ and $\mathrm{Pj}$ are the frequencies of the ith and jth alleles at a locus with 1 allele in a population, respectively (Botstein $e t$ al., 1980).

The population structure of the fig genotypes used in this study was determined using a model based Bayesian clustering implemented in STRUCTURE v.2.3.4 (Pritchard et al., 2000). Possible Ks (where $\mathrm{K}$ is an assumed fixed number of subpopulations in the entire population) from 1 to 12 were examined with 5 replicates. Each replication run was conducted with a burn-in period of 100,000 steps followed by 20,000 Monte Carlo Markov Chain (MCMC) replications using an admixture model and correlated allele frequencies options. The most likely number of subpopulations $(\mathrm{K})$ was determined using the method described by Evanno et al. (2005).

\section{Results and Discussion}

A total of 24 SSR markers were tested to assess genetic variation between 45 caprifigs and two female Turkish fig cultivars (Table 2). While 23 of these SSR markers were polymorphic, LMFC12 was monomorphic with a single allele. The number of polymorphic alleles per SSR marker ranged from 2 (LMFC22-1, LMFC22-2, LMFC25, LMFC27, LMFC31 and LMFC37) to 7 (LMFC30) (Fig. 2). Besides, LMFC22 was considered to be multiple loci (Table 2), therefore, each locus was scored separately because the sizes of each loci were different. Aradhya et al. (2010) reported that the number of alleles ranged from 4 (LMFC22, LMFC31 and LMF35) to 9 (LMFC30) with a mean of 4.9. Similar results were also obtained by Essid et al. (2015) with 20 caprifig 
Table 2. Number of polymorphic alleles, observed heterozygosity (Ho), expected heterozygosity (He) and polymorphism information content (PIC) of SSR markers

\begin{tabular}{|c|c|c|c|c|}
\hline SSR Markers & Number of Alleles & Ho & $\mathrm{He}$ & PIC \\
\hline LMFC11 & 3 & 0.40 & 0.59 & 0.70 \\
\hline LMFC12 & monomorphic & - & - & - \\
\hline LMFC13 & 5 & 0.35 & 0.64 & 0.90 \\
\hline LMFC14 & 3 & 0.42 & 0.57 & 0.80 \\
\hline LMFC15 & 4 & 0.33 & 0.67 & 0.68 \\
\hline LMFC17 & 3 & 0.36 & 0.64 & 0.73 \\
\hline LMFC18 & 4 & 0.30 & 0.70 & 0.42 \\
\hline LMFC19 & 5 & 0.25 & 0.74 & 0.54 \\
\hline LMFC20 & 5 & 0.58 & 0.41 & 0.72 \\
\hline LMFC21 & 3 & 0.63 & 0.37 & 0.72 \\
\hline LMFC22-1 & 2 & 0.54 & 0.45 & 0.78 \\
\hline LMFC22-2 & 2 & 0.49 & 0.50 & 0.98 \\
\hline LMFC23 & 5 & 0.34 & 0.65 & 0.82 \\
\hline LMFC25 & 2 & 0.59 & 0.41 & 0.63 \\
\hline LMFC26 & 3 & 0.70 & 0.30 & 0.72 \\
\hline LMFC27 & 2 & 0.51 & 0.49 & 0.71 \\
\hline LMFC28 & 5 & 0.27 & 0.72 & 0.74 \\
\hline LMFC30 & 7 & 0.18 & 0.81 & 0.81 \\
\hline LMFC31 & 2 & 0.76 & 0.24 & 0.74 \\
\hline LMFC32 & 5 & 0.48 & 0.51 & 0.78 \\
\hline LMFC35 & 3 & 0.43 & 0.57 & 0.62 \\
\hline LMFC36 & 3 & 0.37 & 0.62 & 0.82 \\
\hline LMFC37 & 2 & 0.72 & 0.28 & 0.78 \\
\hline LMFC38 & 4 & 0.34 & 0.65 & 0.70 \\
\hline Mean & 3.56 & 0.45 & 0.54 & 0.73 \\
\hline
\end{tabular}

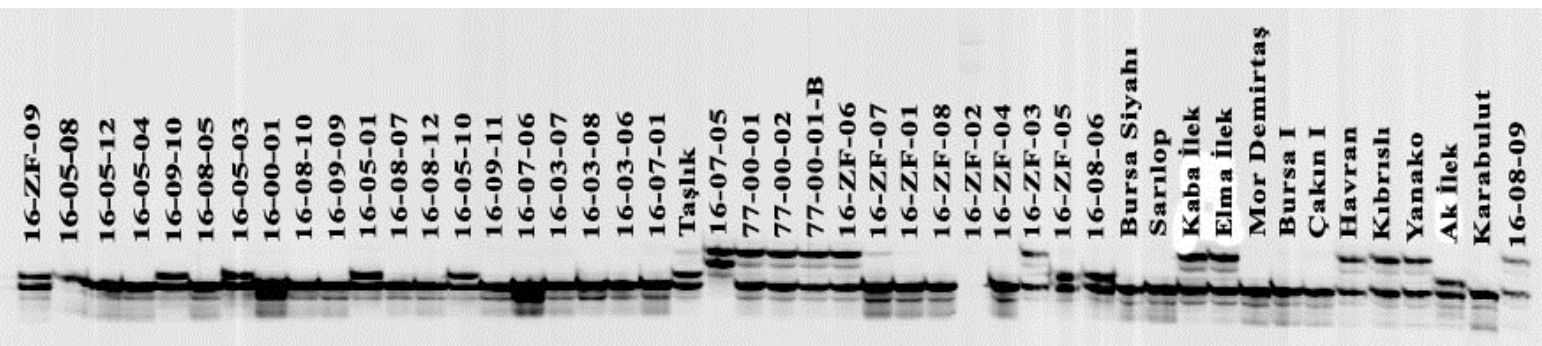

Fig. 2. Polyacrylamide gel picture demonstrating the alleles of LMFC20 SSR marker among 45 caprifig and 2 female fig genotypes

accessions that the number of alleles per locus ranged from 2 (LMFC32, LMFC15, LMFC21, LMFC31, LMFC18, LMFC27, LMFC23) to 6 (LMFC30). Thus, results from present study and previous demonstrated that LMFC30 produced the highest number of alleles per locus.

Among 47 genotypes, 82 polymorphic SSR alleles were amplified, and the average number of alleles per SSR marker was 3.56 (Table 2). Ho values of each SSR marker varied from 0.18 (LMFC30) to 0.76 (LMFC31) with an average of 0.45 while $\mathrm{He}$ values ranged from 0.24 (LMFC31) to 0.81 (LMFC30) with an average of 0.54. Ikegami et al. (2009) found that the average $\mathrm{He}$ and $\mathrm{Ho}$ values were 0.44 and 0.44 , respectively in 19 European and Asian fig varieties. In another study assessing genetic variation among caprifig cultivars, it was reported that the average $\mathrm{He}$ and $\mathrm{Ho}$ values were $0.29,0.33$, respectively (Essid et al., 2015). On the other hand, Khadari et al. (2004) reported an average $\mathrm{He}$ of 0.60 and average of 6.3 alleles per locus with six SSRs and 72 fig cultivars. Our results are also comparable to the results of previous studies and also confirmed that genetic diversity among fig genotypes was large.

The Ho was higher than the He for LMFC20, LMFC21, LMFC22-1, LMFC25, LMFC26, LMFC27, LMFC31 and
LMFC37 while Ho was lower than He for the remaining SSR markers in this study. A heterozygote excess $(\mathrm{Ho}>\mathrm{He})$ was observed for the LMFC15, LMFC31, LMFC18, LMFC27 loci whereas a heterozygote deficiency $(\mathrm{Ho}<\mathrm{He})$ was observed in LMFC24 and MFC2 loci in a study dealing with genetic variation of caprifigs (Essid et al., 2015). According to Giraldo et al. (2008), for all SSRs except LMFC15 and LMFC21, Ho values were higher than the expected.

The polymorphism information content (PIC) value ranged from 0.42 (LMFC18) to 0.98 (LMFC22-2) with an average of 0.73 in this study. Ikegami et al. (2009) found that the highest, the lowest and the average PIC values were 0.82 (LMFC30), 0.26 (LMFC15) and 0.39, respectively. Ferrara et al. (2016) reported that, the lowest PIC observed was 0.07 for LMFC23 and LMFC27 primers while the highest was 0.91 for Frub422 SSR marker. These results suggested that the genetic variation within fig genotypes in this study is high.

The number of gene pools indicated by the STRUCTURE analysis was estimated to be $\mathrm{K}=2$ with the highest $\Delta K$ value (29.86) (Fig. 3), followed by $K=6$ and $K=3$ with $\Delta K s$ of 3.81 and 1.63 , respectively. According to the STRUCTURE analysis, 47 fig genotypes were divided into 
176

two different gene pools. As shown in Fig. 3, gene pool 1 contained 25 genotypes collected from Aydın (7), Balikesir (1), Bursa (13) and Yalova (4) provinces while genepool 2 consisted of 22 individuals collected from Bursa (19); Aydın (2); Yalova (1) provinces. Female cultivars ('Bursa Siyahi' and 'Sarılop') were in gene pool 1 . On the other hand, the genotypes from Aydin and Yalova provinces were mostly placed in gene pool 1. Caprifig genotypes from Bursa province were present in both gene pools although about $86 \%$ of genotypes in gene pool 2 is from Bursa. Similarly, in another study, 90 fig cultivars were placed in two gene pools based on STRUCTURE analysis (Ganopoulos et al., 2015).

A UPGMA dendogram showing the genetic relationships among 47 fig genotypes was developed using Dice similarity matrix (Fig. 4). According to the dendogram, the fig genotypes divided in two distinct clusters (A and B), representing the two gene pools identified by STRUCTURE analysis. Among caprifig genotypes, the highest similarity was between the genotypes '16-ZF-02' and '16-ZF-03' (0.91). Both female cultivars were included in the cluster A with other caprifig genotypes indicating that female and male fig trees are not genetically distinct. Similarly, Saddoud et al. (2005) also found two main groups among 16 Tunisian fig cultivars. In the study of Dalkilic et al. (2011) with RAPD markers, authors determined nine different groups among 43 caprifig genotypes. Essid et al. (2015) identified three main groups among 20 caprifig genotypes.

It has been reported that there is a high number of homonymy, mislabeling and synonymy problems in fig genotypes worldwide. For example, Khadari et al. (2004) observed five cases of mislabeling and homonyms among 75 Moroccan fig accessions using SSR and ISSR markers. Similarly, Dalkilic et al. (2011) also determined three mislabeled and four homonym genotypes among 43 Turkish

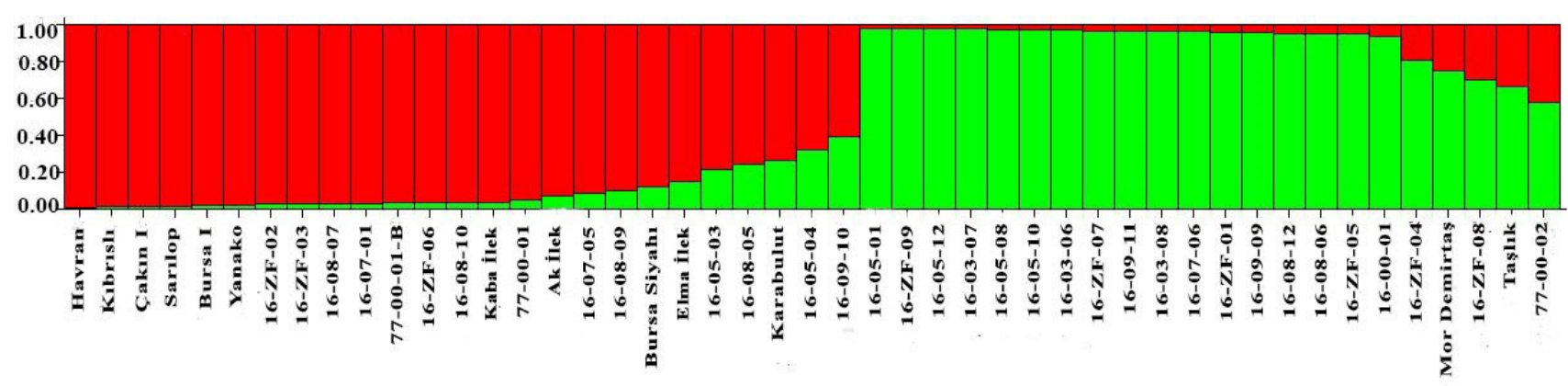

Fig. 3. STRUCTURE bar plot based on 23 SSR markers. Different colours represent different gene pools

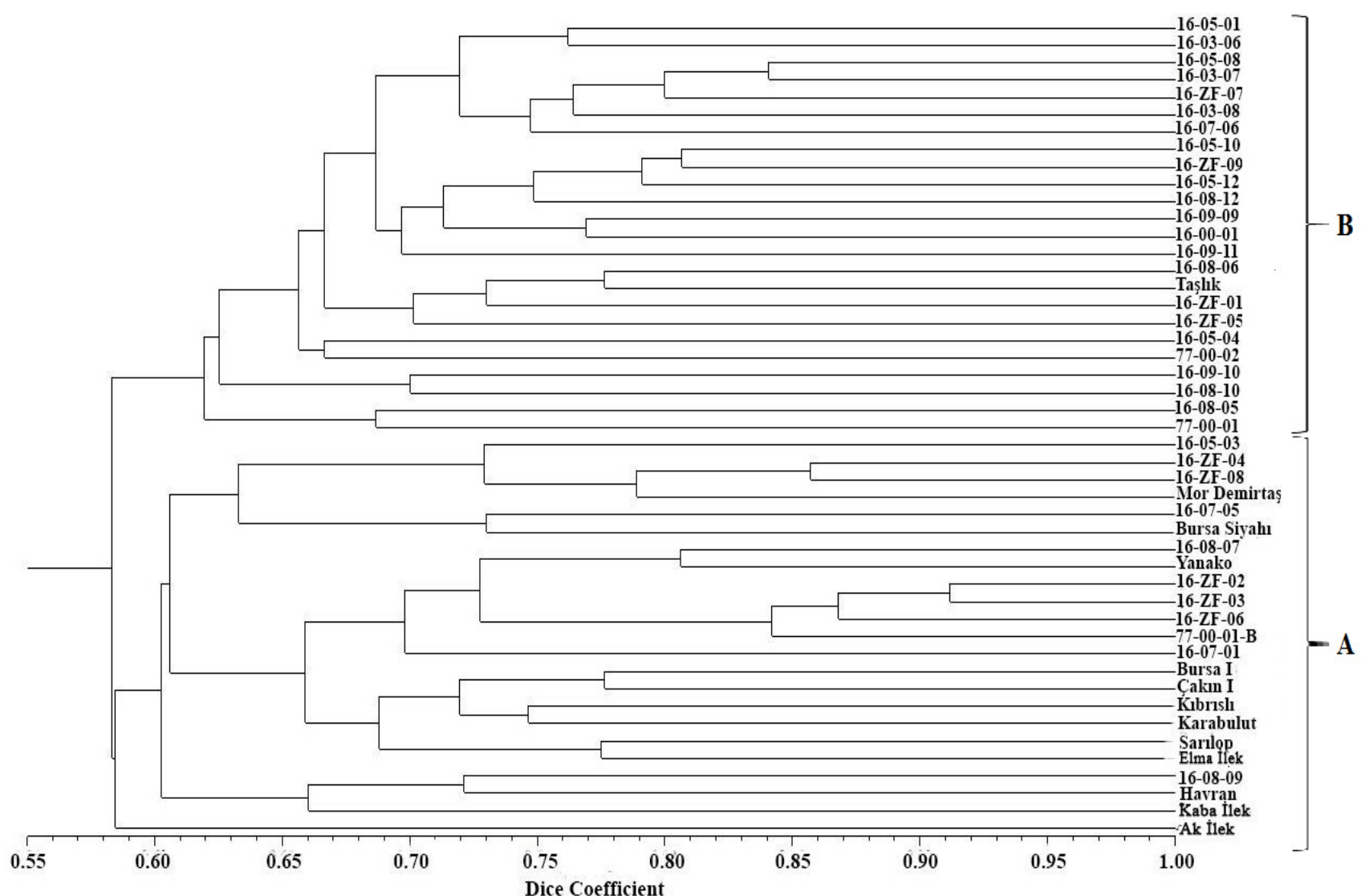

Fig. 4. UPGMA dendrogram based on the Dice similarity of 23 SSR markers showing the genetic relationships among 45 caprifig and 2 female fig genotypes 
caprifig genotypes using RAPD markers. Besides, Essid et al. (2015) detected three undistinguished accessions due to synonyms and analyzed several homonyms within 20 Tunisian caprifig genotypes using SSR markers. However, our results showed that there were no homonyms, mislabeling or synonymies. Thus, all fig genotypes analyzed in this study were unique.

In addition, there was no clear distinction among fig genotypes based on their sites of collection in the present study. Similarly, Giraldo et al. (2008); Dalkilic et al. (2011) and Essid et al. (2015) also found that genotypes from the same regions were placed in different groups. On the other hand, Aradhya et al. (2010) reported that fig accessions from Turkmenistan are genetically different from the Mediterranean and the Caucasus figs.

\section{Conclusions}

The present study proved that SSR markers are reliable technique for identifying genetic diversity of both caprifig and female fig genotypes. Our results showed a high genetic diversity among 45 caprifig genotypes and 2 female cultivars commonly grown in Turkey and these results highlighted that all fig genotypes analyzed in this study were unique. In this respect, this genetic variation could be useful for constituting a caprifig gene bank for future breeding programs and fig production via caprification.

\section{Acknowledgements}

This work was supported by the Republic of Turkey Ministry of Food, Agriculture and Livestock, grant number TAGEM-14/AR-GE/03.

\section{References}

Achtak H, Oukabli A, Ater M, Santoni S, Kjellberg F, Khadari B (2009) Microsatellite markers as reliable tools for fig cultivar identification. Journal of the American Society for Horticultural Science 134:62431.

Aksoy U (1998). Why fig? An old taste and a new perspective. Acta Horticulturae 480:25-35.

Aradhya MK, Stover E, Velasco D, Koehmstedt A (2010). Genetic structure and differentiation in cultivated fig (Ficus carica L.). Genetica 138:681694.

Baraket G, Chatti K, Saddoud O, Mars M, Marrakchi M, Salhi TM, Hannachi A (2009). Genetic analysis of Tunisian fig (Ficus carica L.) cultivars using amplified fragment length polymorphism (AFLP) markers. Scientia Horticulturae 120:487-92.

Botstein D, White RL, Skolnick M, Davis RW (1980). Construction of a genetic-linkage map in man using restriction fragment length polymorphisms. The American Journal of Human Genetics 32:314 331.

Cabrita LF, Aksoy U, Hepaksoy S, Leitao JM (2001). Suitability of isozyme, RAPD and AFLP markers to assess genetic differences and relatedness among(Ficus carica L.) clones. Scientia Horticulturae 87:261-273.

Caliskan O, Polat AA (2008). Fruit characteristics of fig cultivars and genotypes grown in Turkey. Scientia Horticulturae 115:360-367.
Caliskan O, Polat AA, Celikkol P, Bakir M (2012). Molecular characterization of autochthonous Turkish fig accessions. Spanish Journal of Agricultural Research 10(1):130-140.

DalkilicZ, Mestav HO,Dalkilic GG, Kocatas H (2011). Genetic diversity of male fig (Ficus carica caprificus L.) genotypes with random amplified polymorphic DNA (RAPD) markers. African Journal of Biotechnology 10(4):519-526.

Dice LR (1945). Measures of the amount of ecologic association between species. Ecology 26:297-302

Essid A, Aljane F, Ferchichi A, Hormaza JI (2015). Analysis of genetic diversity of Tunisian caprifig (Ficus carica L.) accessions using simple sequence repeat (SSR) markers. Hereditas 152:1.

Evanno G, Regnaut S, Goudet J (2005). Detecting the number of clusters of individuals using the software STRUCTURE: Asimulation Study. MolecularEcology 14:2611-2620.

FAOSTAT (2013). Food and Agriculture Organization of the United Nation Statistics for 2013 January 2017 from http://www.fao.org/faostat/en/\#home.

FAOSTAT (2014). Food and Agriculture Organization of the United Nation Statistics for 2014. January 2017 from http://www.fao.org/faostat/en/\#home.

Ferguson L, Michailides TJ, Shorey HH(1990). The California fig industry. Horticultural Reviews 12:409-490.

Ferrara G, Mazzeo A, Pacucci C, Matarrese AMS, Tarantino A, Crisosto C, ... Gadaleta A (2016). Characterization of edible fig germplasm from Puglia, southeastern Italy: Is the distinction of three fig types (Smyrna, San Pedro and Common) still valid? Scientia Horticulturae 205:52-58.

Flaishman, MA, Rodov V, Stover E (2008). The fig: botany, horticulture, and breeding. Horticultural Reviews 34:113-196.

Futterer J, Gisel A, Iglesias V, Kloti A, Kost B, Mittelsten-Scheid O, .... Wang ZY (1995). Standard molecular techniques for the analysis of transgenic plants. In: Potrykus I, Spangenberg G (Eds). Gene transfer to plants. New York, NY, USA:Springer-Verlagpp 215-263.

Ganopoulos I, Xanthopoulou A, Molassiotis A, Karagiannis E, Moysiadis T, Katsaris P, ... Madesis P (2015). Mediterranean basin Ficus carica L.: from genetic diversity and structure to authentication of a protected designation of origin cultivar using microsatellite markers. Trees 29:1959.

Giraldo E, Viruel MA, López-Corrales M, Hormaza JI (2005). Characterisation and cross-species transferability of microsatellites in the common fig (Ficus carica L.). The Journal of Horticultural Science and Biotechnology 80:217-224.

Giraldo E, Lopez-Corrales M, Hormaza JI (2008). Optimization of the management of an ex-situ germplasm bank in common fig with SSRs. Journal of the American Society for Horticultural Science 133:69-77.

Giraldo E, Lopez-Corrales M, Hormaza JI (2010). Selection of the most discriminating morphological qualitative variables for characterization of fig. Journal of the American Society for Horticultural Science 135(3):240-249.

Guasmi F, Ferchichi A, Farés K, Touil L (2006). Identification and differentiation of Ficus carica L. cultivars using inter simple sequence repeat markers. African Journal of Biotechnology 5:1370-1374.

Ikegami H, Nogata H, Hirashima K, Awamura M, Nakahara T (2009). 
178

Analysis of genetic diversity among European and Asian fig varieties (Ficus carica L.) using ISSR, RAPD and SSR markers. Genetic Resources and Crop Evolution 56:201-209.

Janick J (2005). The origin of fruits, fruit growing, and fruit breeding. Plant Breeding Reviews 25:255-320.

Khadari B, Lashermes PH, Kjellberg F (1995). RAPD fingerprints for identification and genetic characterization of fig (Ficus carica L.) genotypes. Journal of Genetics and Breeding 49:77-86.

Khadari B, Hochu I, Santoni S, Kjellberg F (2001). Identification and characterization of microsatellite loci in the common fig (Ficus carica L.) and representative species of the genus Ficus. Molecular Ecology Notes 1:191-193.

Khadari B, Oukabli A, Ater M, Mamouni A, Roger JP, Kjellberg F (2004). Molecular characterization of Moroccan fig germplasm using inter simple sequence repeat and simple sequence repeat markers to establish a reference collection. HortScience 40(1):29-32.

Kjellberg F, Gouyon PH, Ibrahim M, Raymond M, Valdeyron G (1987). The stability of the symbiosis between dioecious figs and their pollinators: A study of Ficus carica L. and Blastophagapsenes L. Evolution 41:693-704.

Levene $H$ (1949). On a matching problem arising in genetics. Annals of Mathematics and Statistics 20:91-94.

Mawa S, Husain K, Jantan I (2013). Ficus carica L. (Moraceae): Phytochemistry, Traditional Uses and Biological Activities. EvidenceBased Complementary and Alternative Medicine. doi: $10.1155 / 2013 / 974256$.
Perez-Jiménez M, López B, Dorado G, Pujadas-Salvá A, Guzmán G, Hernandez P (2012). Analysis of genetic diversity of southern Spain fig tree (Ficus carica L.) and reference materials as a tool for breeding and conservation. Hereditas 149:108-113.

Pérez-Sánchez R, Morales-Corts MR, Gómez-Sánchez MA (2016). Agromorphological diversity of traditional fig cultivars grown in centralwestern Spain. Genetika 48(2):533-546.

Pritchard JK, Stephens M, Rosenberg NA, Donnelly P (2000). Association mapping in structured populations. American Journal of Human Genetics 67:170-181.

Rahemi M,Jafari M(2008). Effect of caprifig type on quantity and quality of Estahban dried fig Ficus carica cv. Sabz. Acta Horticulturae 798:249-252.

Saddoud O, Salhi-Hannachi A, Chatti K, Mars M, Rhouma A, Marrakchi M, Trifi M (2005). Tunisian fig (Ficus carica L.) genetic diversity and cultivar characterization using microsatellite markers. Fruits 60:143-53.

Schuelke M (2000). An economic method for the fluorescent labelling of PCR fragments. Nature Biotechnology 18:233-234.

Stover E, Aradhya M, Ferguson L, Crisosto CH (2007). The Fig: Overview of an Ancient Fruit. HortScience 42(5):1083-1087.

Trad M, Le Bourvellec C, Gaaliche B, Ginies C, Renard CMGC, Mars M (2013). Caprification modifies polyphenols but not cell wall concentrations in ripe figs. Scientia Horticulturae 160:115-122

Yeh FC, Yang RC, Boyle TBJ, YeZH, Mao JX (1997). POPGENE the user-friendly shareware for population genetic analysis molecular biology and biotechnology. Retrieved 2000 April 10 from http://wwwualbertaca/ fyeh. 